\title{
PENGARUH INVESTASI DAN BELANJA PEMERINTAH TERHADAP PERTUMBUHAN EKONOMI DAN PAD DI KABUPATEN BERAU
}

\author{
Abdurrahman U \\ Fakutlas Ekonomi Universitas Mulawarman \\ E-mail:Perpusmsi-unmul@gmail.com
}

\begin{abstract}
The first purpose of the research was to determine the direct and indirect influence of Investment and Government Expenditure on Economic Growth and Regional Income in Berau, while the second purpose was to identify the direct influence of Economic Growth on Regional Income in Berau. In order to get accurate results, the research implemented 2 regression lines to analyze the data. The finding shown in Line Diagram 1 indicated that investment and government expenditure had a direct and significant effect on economic growth in Berau. Meanwhile, on the Line Diagram 2, it appears that investment and government expenditure had a direct effect and an indirect but significant impact on Regional Income in Berau.
\end{abstract}

Keywords: Investment, Government Expenditure, Economic Growth, Regional Income

\begin{abstract}
Abstrak
Tujuan Penelitian ini adalah mengetahui pengaruh langsung dan tidak langsung Investasi dan Belanja Pemerintah Terhadap Pertumbuhan Ekonomi dan Pendapatan Asli Daerah di Kabupaten Berau, serta mengetahui pengaruh langsung Pertumbuhan Ekonomi terhadap Pendapatan Asli Daerah di Kabupaten Berau. Alat analisis yang digunakan yaitu regresi dengan 2 jalur. Diagram Jalur 1 menunjukkan bahwa variabel Investasi dan Belanja Pemerintah mempunyai pengaruh langsung dan signifikan terhadap Pertumbuhan Ekonomi di Kabupaten Berau. Diagram Jalur 2 menunjukkan bahwa variabel Investasi dan Belanja Pemerintah mempunyai pengaruh langsung dan tidak langsung tetapi signifikan terhadap Pendapatan Asli Daerah di Kabupaten Berau.
\end{abstract}

Kata Kunci: Investasi, Belanja Pemerintah, Pertumbuhan Ekonomi, Pendapatan Asli Daerah

Modal merupakan pendorong perkembangan ekonomi dan merupakan sumber untuk menaikan tenaga produksi yang semuanya membutuhkan kepandaian penduduknya dan mengadakan investasi untuk mengolahnya, selain itu ditentukan pula adanya pendorong untuk mengadakan investasi atas dana yang diperoleh dari tabungan masyarakat maupun pinjaman luar negeri. Sehubungan dengan itu diperlukan upaya 
peningkatan pergerakan dana dari dalam negeri. Penanaman modal atau investasimerupakan langkah awal kegiatan produksi. Pada posisi semacam ini investasi pada hakikatnya juga merupakan langkah awal kegiatan pembangunan ekonomi. Dalam upaya menumbuhkan perekonomian setiap negara senantiasa menciptakan iklim yang dapat menggairahkan investasi. Sasaran yang dituju bukan hanya masyarakat kalangan swasta dalam negeri, tapi juga investor asing. Oleh karena itu untuk mencapai sasaran tersebut diperlukan berbagai sarana penunjang, antara lain tata hukum yang mendorong, menggerakkan, dan mengandalkan berbagai kegiatan pembangunan di bidang ekonomi.

Kabupaten Berau adalah Kabupaten yang kaya dengan sumber daya alamnya yang menjadi salah satu penarik para investor menanamkan modal. Peran investasi PMA dan PMDN terhadap ekonomi Kabupaten Berau untuk pembiayaan pembangunan dan perekonomian di berbagai sektor ekonomi, selain itu modal untuk pengelolaan dan mendayagunakan sumber daya alam, terutama minyak, gas, batubara, dan minyak kelapa sawit, yang mana dapat meningkatkan penerimaan pendapatan asli daerah.

Data investasi Kabupaten Berau menunjukkan tentang PMA Kabupaten Berau mengalami kenaikan setiap tahunnya daritahun 2002 sebesar 1.200.000 US Dolar ke tahun 2007 naik sebesar 4.302.543 US Dolar, dan tahun 2008 mengalami kenaikan sebesar 58.102.302 US Dolar, di tahun 2010 mengalami penurunan sebesar 19.668.414 US Dolar, dan naik kembali di tahun 2011 sebesar 125,448,500 US Dolar. Iniberarti menunjukkankenaikan investasidi Kabupaten Berau. (BPS Kabupaten Berau).

Pergerakan perekonomian masyarakat Kabupaten Berau sangat dinamis dan fluktuatif. Terjadinya pertumbuhan yang sangat berpluktuasi ini dapat diartikan bahwa pertumbuhan lapangan kerja yang terjadi bukan pada sektor formal, melainkan sektor non formal. Untuk memacu pertumbuhan ekonomi yang lebih statis, maka investasi baik asing maupun pemerintah sangat diperlukan. Karena itu untuk mendorong tumbuhnyaperekonomian dan pendapatan asli daerah itu sendiri.

Pada masa orde baru terjadi perubahan yaitu penyumbang terbesar Produk Domestik Bruto Kabupaten Berau yang semula adalah dari sektor pertanian, berubah menjadi sektor produksi pertambangan. Sektor ini memerlukan modal yang sangat besar sehingga diperlukan PMA untuk pengolahannya sehingga sumber ini menjadi sumber penghambat pendapatan asli daerahkabupaten Berau.

Pengertian Keuangan Negara yang dikemukakan oleh beberapa para ahli antara lain, Baswir (2001: 13) mengemukakan bahwa Keuangan Negara adalah semua hak dan kewajiban negara, serta segala sesuatu yang berkaitan dengan hak dan kewajiban tersebut, yang dapat dinilai dengan uang menjadi hak-hak negara adalah segala hak atau usaha yang dilakukan oleh pemerintah dalam mengisi kas negara, misalnya hak mencetak uang, menarik pajak dan retribusi, serta mengadakan pinjaman, sedangkan kewajiban negara adalah kewajiban pemerintah untuk menyelenggarakan tugas negara, sebagaimana tercantum dalam pembukaan UUD 1945, GBHN, dan UndangUndang APBN yang pada prinsipnya adalah untuk mensejahterakan rakyat, melayani masyarakat umum, dan sebagai aparat pembangunan (agent of development), daerah membutuhkan dana.

Menurut Suryana (2000) anggaran pemerintah adalah hasil dari suatu perencanaan yang berupa daftar mengenai bermacammacam kegiatan terpadu, baik menyangkut 
penerimaannya maupun pengeluarannya yang dinyatakan dalam satuan uang dalam jangka waktu tertentu. Pemerintah menetapkan anggaran negaranya dalam Anggaran Pendapatan dan Belanja Negara (APBN) yang ditetapkan tiap tahun dengan undang-undang setelah mendapatkan persetujuan Dewan Perwakilan Rakyat (DPR).

Anggaran pemerintah merupakan salah satu alat politik fiskal untuk mempengaruhi arah dan percepatan pendapatan nasional. Adapun mengenai anggaran yang akan digunakan tergantung pada keadaan ekonomi yang dihadapi. Dalamkeadaan ekonomi yang normal dipergunakan anggaran pemerintah yang seimbang, kemudian dalam keadaan ekonomi yang deflasi biasanya dipergunakan anggaran pemerintah yang defisit dan sebaliknya dalam keadaan ekonomi yang inflasi dipergunakan anggaran pemerintah yang surplus.

Anggaran Pendapatan dan Belanja Negara (APBN) merupakan rencana keuangan tahunan pemerintah negara yang disetujui oleh Dewan Perwakilan Rakyat (DPR). Dalam menyusun suatu anggaran harus berkaitan antara dana-dana yang akan dikeluarkan dan tujuan yang akan dicapai. Anggaran Pendapatan dan Belanja Negara (APBN) berisikan daftar sistematis dan terperinci yang memuat rencana penerimaan dan pengeluaran negara dalam satu tahun anggaran (1 Januari - 31 Desember). Namun ada juga yang dimulai dari 1 April dan berakhir pada 31 Maret tahun berikutnya. Pola Anggaran Pendapatan dan Belanja Negara (APBN) dan realisasinya adalah untuk melaksanakan tugas seharihari (rutin) dalam rangka pelaksanaan kegiatan di bidang pemerintahan.

Rancangan Anggaran Pendapatan dan Belanja Negara (APBN) diajukan oleh presiden dalam bentuk rancangan undang- undang kepada Dewan Perwakilan Rakyat (DPR). Setelah melalui pembahasan, Dewan Perwakilan Rakyat (DPR) menetapkan undang-undang tentang Anggaran Pendapatan dan Belanja Negara (APBN) selambatlambatnya dua bulan sebelum tahun anggaran dilaksanakan. Berdasarkan perkembangannya jika di tengah-tengah tahun anggaran yang berjalan Anggaran Pendapatan dan Belanja Negara (APBN) dapat mengalami perubahan. Pada kondisi tersebut pemerintah harus mengajukan kembali Rancangan Undang-Undang Perubahan Anggaran Pendapatan dan Belanja Negara (APBN) untuk mendapatkan persetujuan Dewan Perwakilan Rakyat (DPR) kembali.

Anggaran Pendapatan dan Belanja Negara (APBN) memiliki enam fungsi dalam rangka membentuk struktur perekonomian negara antara lain: 1) Fungsi Otoritas yaitu Bahwa Anggaran Pendapatan dan Belanja Negara (APBN) menjadi dasar untuk melaksanakan pendapatan dan belanja negara pada tahun yang bersangkutan, dengan demikian pembelanjaan atau pendapatan dapat dipertanggungjawabkan kepada rakyat; 2) Fungsi Perencanaan, bahwa Anggaran Pendapatan dan Belanja Negara (APBN) dapat menjadi pedoman bagi negara untuk merencanakan kegiatan pada tahun tersebut. Bila pembelanjaan telah direncanakan sebelumnya, maka negara dapat membuat rencana-rencana untuk mendukung pembelanjaan tersebut. Misalnya telah direncanakan atau dianggarkan akan membangun proyek pembangunan jalan, maka pemerintah dapat mengambil tindakan untuk persiapan proyek tersebut agar bisa berjalan dengan lancar; 3) Fungsi Pengawasan, Anggaran Pendapatan dan Belanja Negara (APBN) harus menjadi pedoman untuk menilai apakah kegiatan penyelenggaraan pemerintah negara sesuai dengan 
Ekonomika-Bisnis Vol. 4 No.1 Bulan Januari Tahun 2013. Hal 55-62

ketentuan yang telah ditetapkan; 4) Fungsi Alokasi, Bahwa suatu Anggaran Pendapatan dan Belanja Negara (APBN) harus diarahkan untuk mengurangi penggangguran dan pemborosan sumber daya serta meningkatkan efisiensi dan efektivitas perekonomian; 5) Fungsi Distribusi, Bahwa kebijakan Anggaran Pendapatan dan Belanja Negara (APBN) harus memperhatikan rasa keadilan dan kepatutan; 6) Fungsi Stabilitas Bahwa Anggaran Pendapatan dan Belanja Negara (APBN) menjadi alat untuk memelihara dan mengupayakan keseimbangan fundamental perekonomian.

Dengan berlakunya Undang-Undang Otonomi Daerah Nomor: 22 tentang pemerintah daerah dan undang-undang nomor: 25 tentang Perimbangan Keuangan antara pemerintah pusat dan daerah, maka pemerintah daerah memilikikewenangan untuk melaksanakan kegiatannya dan menjalakan pembangunan serta kewenangan yang lebih luas dalam mendapatkan sumber-sumber pembiayaan, baik yang berasal dari daerah itu sendiri maupun dana yang berasal dari pusat. Berdasarkan penjelasan undangundang nomor: 25 tahun 1999 dijelaskan bahwa: "adalah penerimaan daerah dari sumber-sumber dalam wilayah sendiri yang dipungut berdasarkan peraturan daerah sesuai dengan peraturan perundangundangan yang berlaku, yang terdiri dari:

Pertama, Sumber penerimaan daerah dapat berasal dari pertumbuhan ekonomi, Economic growth is the increase in the amount of the goods and services produced by an economy over time. It is conventionally measured as the percent rate of increase in real gross domestic product, or real GDP. Growth is usually calculated in real terms. In economics, "economic growth" or "economic growth theory" typically refers to growth of po- tential output, i.e., production at "full employment," which is cause by growth in aggregate demand or observed output. (pertumbuhan ekonomi adalah peningkatan jumlah barang dan jasa yang dihasilkan oleh suatu perekonomian dari waktu ke waktu. Diukur secara konvensional sebagai laju persen kenaikan dalam produk domestik bruto riil, atau GDP riil. Pertumbuhan biasanya dihitung secara riil. Dalam ilmu ekonomi, "pertumbuhan ekonomi” atau "teori pertumbuhan ekonomi" biasanya mengacu pada pertumbuhan output potensial, seperti: produksi di "lapangan kerja", yang disebabkan oleh pertumbuhan permintaan agregat atau output yang diamati) (Simon, 2002).

Menurut Mankiw (2006) Pertumbuhan ekonomi adalah kenaikan pendapatan nasional secara berarti (dengan meningkatnya pendapatan perkapita) dalam suatu periode perhitungan tertentu. Schumpeter pertumbuhan ekonomi adalah pertambahan output (pendapatan nasional) yang disebabkan oleh pertambahan alami daritingkat pertambahan penduduk dan tingkat tabungan.

Pertumbuhan ekonomi merupakan istilah bagi negara yang telah maju untuk menyebut keberhasilan pembangunannya, sementara itu untuk negara yang sedang berkembang digunakan istilah pembangunanekonomi. Apapun istilah dan definisinya, yang pasti adalah bahwa pertumbuhan ekonomi mengkaitkan dan menghitung antara tingkat pendapatan nasional dari satu periode ke periode berikutnya.

Kedua, Investasi adalah penambahan barang modal secara netto yang positif. Investasi dapat dibedakan menjadi dua jenis, yaitu investasi riil dan investasi finansial. Yang dimaksud dengan investasi riil adalah investasi terhadap barang-barang tahan lama 
(barang-barang modal) yang akan digunakan dalam proses produksi. Sedangkan investasi finansial adalah investasi terhadap surat-surat berharga, misalnya pembelian saham, obligasi, dan surat bukti hutang lainnya. (Simon, 2002), pertimbangan-pertimbangan utama yang perlu dilakukan dalam melakukan (memilih) suatu jenis investasi riil adalah tingkat bunga pinjaman yang berlaku $(i)$, tingkat pengembalian (rate or return), dari barang modal, dan prospek (harapan berkembang) proyek investasi (Todaro, 2006), arus sumbersumber keuangan internasional dapat terwujud dalam dua bentuk. Yang pertama adalah penanaman modal asing yang dilakukan pihak swasta (private foreign investment) dan investasi portofolio, terutama berupa penanaman modal asing "langsung" yang biasanya dilakukan oleh perusahaan-perusahaan raksasa multinasional. Di samping itu, terdapat pula arus permodalan serupadari bank-bank swasta internasional, yang dana investasinya berupa portofolio.

Sudut fokus penelitian ini yang terpenting adalah pengaruh investasi dan Belanja pemerintah terhadap pertumbuhan ekonomi. Penelitian ini bertujuan melihat peran investasi erat kaitanya dalam pendapatan asli daerah dan peningkatan PDRB.

\section{Metode Penelitian}

Jenis data yang digunakan adalah data sekunder yang didapat dari Badan Pusat Statistik Kabupaten Berau dan Dinas Pendapatan Daerah selama kurun waktu 20012011. Adapun data-data yang dibutuhkan yaitu Investasi, Belanja daerah, Pertumbuhan ekonomi, PAD. Teknik mengumpulkan data dalam penelitian ini menggunakan pendekatan Library Research Approach (Pendekatan Riset Kepustakaan).
Analisis Jalur atau yang lebih dikenal luas sebagai Path Analysis merupakan suatu metode pendekomposisian korelasi ke dalambagian-bagian yang berbeda untukmenginterpretasikan suatu pengaruh (effect). Dalam analisis jalur yang distandarkan korelasi dapat dipecah kedalam komponen-komponen struktural (kausal) dan nonstruktural (nonkausal) didasarkan teori yang dinyatakan dalam diagram jalur. Total Efek Struktural dapat didekomposisi: Langsung dan Tidak Langsung. Variabel eksogen (exogenous variable) mencerminkan variabel penyebab, dan variabel endogen (endogenous variable) sebagai variabel akibat.

Langkah pertama analisis jalur adalah menerjemahkan hipotesis penelitian yang bentuknya proposisional ke dalam bentuk diagram yang disebut diagram jalur. Pada saat menggambarkan diagram jalur ada beberapa perjanjian: 1) Hubungan antar variabel digambarkan oleh anak panah yang bisa berkepala tunggal $(\rightarrow)$ atau single headed arrow, dan berkepala dua $(\leftrightarrow)$ atau double headed arrow; 2) Panah berkepala satu menunjukkan pengaruh dari sebuah variabel eksogen terhadap sebuah variabel endogen; 3) Panah berkepala dua menggambarkan hubungan korelatif antar variabel eksogen.

\section{Hasil Penelitian dan Pembahasan}

Berdasarkan analisis yang dilakukan terhadap data-data yang telah didapatkan menunjukan hasil penelitian ini menemukan adanya pengaruh yang tidak signifikan antara variabel investasi terhadap pertumbuhan ekonomi, untuk menguji signifikansi masingmasing variabel secara individu dilakukan Uji t-statistik. Variabel investasi tidak berpengaruh signifikan terhadap pertumbuhan ekonomi, karena tingkat (sig $>0,05$ ) yaitu $(0,881>0,05)$. 
Penelitian ini sejalan dengan dengan Abdul (2010) melakukan penelitian investasi tidak berpengaruh signifikan terhadap ProdukDomestik RegionalBruto (PDRB) di Kalimantan Timur.

Hasil analisis data lain menemukan adanya pengaruh yang signifikan antara variabel belanja pemerintah terhadap pertumbuhan ekonomi, untuk menguji signifikansi masingmasing variabel secara individu dilakukan Uji t-statistik. Variabel belanja pemerintah berpengaruh signifikan terhadap pertumbuhan ekonomi, karena tingkat (sig $<0,05$ ) yaitu $(0,007<0,05)$.

Penelitian ini sejalan dengan dengan Aminuddin (2010), melakukan penelitianpengeluaran pemerintah berpengaruh signifikan terhadap produk domestik regional bruto (PDRB) di Kabupaten Kutai Barat.

Belanja Pemerintah adalah pengeluaran yang digunakan untuk pemeliharaan dan penyelenggaraan pemerintah yang meliputi belanja pegawai, belanja barang, pembayaran bunga utang, subsidi, dan pengeluaran rutin lainnya. Melalui pengeluaran rutin, pemerintah dapat menjalankan misinya dalam rangka menjaga kelancaran penyelenggaraan pemerintahan, kegiatan operasional dan pemeliharaan aset negara, pemenuhan kewajiban pemerintah kepada pihak ketiga, perlindungan kepada masyarakat miskin dan kurang mampu, serta menjaga stabilitas perekonomian(Djunasien dan Hidayat, 2002:90).

Hasil analisis untuk pengaruh investasi menemukan adanya pengaruh yang signifikan antara variabel investasi terhadap pendapatan asli daerah, untuk menguji signifikansi masing-masing variabel secara individu dilakukan Uji t-statistik. Variabel investasi berpengaruh signifikan terhadap pendapatan asli daerah, karena tingkat (sig $<0,05)$ yaitu $(0,002<0,05)$.
Penelitian ini sejalan dengan dengan Muh. Fadli (2010), melakukan penelitian investasi berpengaruh signifikan terhadap PAD di Kutai Timur. Hasil analisis melaluiuji jalur ini menemukan adanya pengaruh yang signifikan antara variabel pengeluaran pemerintah terhadap pendapatan asli daerah, untuk menguji signifikansi masing-masing variabel secara individu dilakukan Uji t-statistik. Variabel pengeluaran pemerintah berpengaruh signifikan terhadap pendapatan asli daerah, karena tingkat ( sig $<0,05$ ) yaitu $(0,000<0,05)$.

Penelitian ini sejalan dengan Aminuddin (2010), melakukan penelitian pengeluaran pemerintah berpengaruh signifikan terhadap PAD di Kabupaten Kutai Barat. Hasil analisis data pengaruh pertumbuhan ekonomi ini menemukan adanya pengaruh yang signifikan antara variabel pertumbuhan ekonomi terhadap PAD. Artinya secara empirik terlihat bahwa peningkatan pertumbuhan ekonomi setiap tahunnya diikuti oleh peningkatan pendapatan asli daerah (PAD) Kabupaten Berau.

Untuk mengukur signifikansi melalui Uji t-statistik. Variabel pertumbuhan ekonomi memiliki pengaruh signifikan terhadap PAD sebesar $(0,000<0,05)$, karena tingkat ( sig<0,05).

Pengaruh tidak langsung investasi terhadap PAD melalui Pertumbuhan Ekonomi sebesar -0,168 atau sebesar -16,8\%. Artinya Investasi memberikan pengaruh terhadap pendapatan asli daerah (PAD) melalui pertumbuhan ekonomi sebesar-16,8\% . Artinya investasi memberikan pengaruh sangat kecil terhadap PAD melalui Pertumbuhan Ekonomi di Kabupaten Berau. Hasil penelitian ini menemukan adanya pengaruh tidak langsung dan signifikan antara variabel investasi terhadap PAD. Artinya secara empirik terlihat bahwa peningkatan investasi 
setiap tahunnya diikutioleh peningkatan pendapatan asli daerah (PAD) Kabupaten Berau. Investasi merupakan sebagai pendorong utama perekonomian, baik yang bersumber dari PMDN maupun PMA, tentunya diperlukan dalam mencapai suatu target pertumbuhan ekonomi di mana pertumbuhan ekonomi merupakan unsur penting dalam sebuah proses pembangunan yang mana akan meningkatkan pendapatan asli daerah Kabupaten Berau.

Pengaruh tidak langsung Belanja Pemerintah terhadap PAD melalui Pertumbuhan Ekonomi di Kabupaten Berau sebesar 0,504 atau sebesar 50,4\%. Artinya Pengeluaran Pemerintah memberikan pengaruh terhadap pendapatan asli daerah (PAD) melalui pertumbuhan ekonomi sebesar 50,4\%. Belanja pemerintah digunakan untuk pemeliharaan dan penyelenggaraan pemerintah yang meliputi belanja pegawai, belanja barang, pembayaran bunga utang, subsidi, dan pengeluaran rutin lainnya. Melalui pengeluaran rutin, pemerintah dapat menjalankan misinya dalam rangka menjaga kelancaran penyelenggaraan pemerintahan, kegiatan operasional dan pemeliharaan aset negara, pemenuhan kewajiban pemerintah kepada pihak ketiga, perlindungan kepada masyarakat miskin dan kurang mampu, serta menjaga stabilitas perekonomian. Sehingga dengan pembangunan berjalan dengan baik maka akan mendatangkan atau meningkatkan PAD disertai dengan meningkatnya juga pertumbuhan ekonomi di daerah Kabupaten Berau.

\section{Penutup}

Investasi berpengaruh langsung dan tidak signifikan terhadap pertumbuhan ekonomi di Kabupaten Berau. investasi pemerintah baik asing dan domestik memberikan pengaruh negatif atau tidak berpengaruh sig- nifikan terhadap pertumbuhan ekonomi. Karena investasi yang di Kabupaten Berau baru bisa dirasakanmasyarakan dalam jangka waktu yang panjang ini dikarenakan pembangunan yang lambat di Kabupaten Berau.

Belanja Pemerintah berpengaruh langsung dan signifikanterhadap pertumbuhanekonomi di Kabupaten Berau. Belanja pemerintah di sini disesuaikan dengan adanya pengeluaran pemerintah seperti pengeluaran pembangunan 20 sektor. Nantinya pengeluaran pemerintah tersebut akan digunakan oleh masyarakat seperti contoh pembangunan tempat wisata. Masyarakat yang menggunakan tempat wisata tersebut tentunya akan dikenai pajak masuk, biaya parkir, dan lain-lain. Di mana pendapatan yang diperoleh tersebut akan diterima pemerintah suatu daerah.

Investasi berpengaruh langsung dan signifikan terhadap PAD di Kabupaten Berau. Hasil penelitian menerangkan bahwa investasi berpengaruh signifikan terhadap PAD di Kabupaten Berau. Investasi berpengaruh langsung ke pertumbuhan ekonomi melalui PAD (pendapatan asli daerah). Hal ini dikarenakan investasi merupakan faktor yang mendudkung peningkatan $\mathrm{PAD}$, seperti peningkatan pajak daerah dan lainlain.

Pengeluaran Pemerintah berpengaruh langsung dan signifikan terhadap PAD di Kabupaten Berau. Dengan adanya pengeluaran pemerintah seperti pengeluaran pembangunan dan belanja pegawai tentunya akan dikenai pajak. Di mana pendapatan yang diperoleh tersebut akan diterima pemerintah suatu daerah. Artinya pembangunan pemerintah akan memberikan dampak positif terhadap bertambahnya PAD (Pendapatan Asli Daerah).

Pertumbuhan ekonomi berpengaruh langsung dan signifikan terhadap PAD di 
Kabupaten Berau. Semakin besar pertumbuhan ekonomi suatu daerah maka di asumsikan pendapatan fiskalnya tinggi. Terciptanya lapangan pekerjaan yang tinggi, berkurangnya pengangguran, meningkatnya pendapatan masyarakat merupakan gambaran pertumbuhan ekonomi yang tinggi. Semakin besar pertumbuhan ekonomi juga dapat menciptakan sumber-sumber penerimaan yang baru.

Investasiberpengaruh tidak langsung dan signifikan terhadap PAD melalui pertumbuhan ekonomi di Kabupaten Berau. Investasi memberikan pengaruh sangat kecil terhadap PAD melalui Pertumbuhan Ekonomi di Kabupaten Berau. Artinya secara empirik terlihat bahwa peningkatan investasi setiap tahunnya diikutioleh peningkatan pendapatan asli daerah (PAD) Kabupaten Berau.

Belanja Pemerintah berpengaruh tidak langsung terhadap PAD melalui pertumbuhan ekonomi di Kabupaten Berau. Dalam hal ini Belanja Pemerintah memberikan pengaruh terhadap pendapatan asli daerah (PAD) melalui pertumbuhan ekonomi. Belanja pemerintah digunakan untuk pemeliharaan dan penyelenggaraan pemerintah yang meliputi belanja pegawai, belanja barang, pembayaran bunga utang, subsidi, dan pengeluaran rutin lainnya. Sehingga dengan pembangunan berjalan dengan baik maka akan mendatangkan atau meningkatkanPAD disertai dengan meningkatnya juga pertumbuhan ekonomi di daerah Kabupaten Berau.

\section{DAFTAR PUSTAKA}

Devas, N., B,Binder., K.Davey, R.Kelly, 1989. Keuangan Pemerintah Daerah di Indonesia. Penerbit Universitas Indonesia. Jakarta.

Davey, K.J. 1988. Pembiayaan Pemerintah Daerah. UI-Press. Jakarta.
Downing, B. Paul. 1992. "The Revenue Potential of User Charges in Municipal Finance". Jurnal Public Finance Quartely, Volume 20,Nomor 4, 512 527.

Mc Queen, Jim. 1998. “Development of a Model User Fees-A Model on Policy Development in Creating and Maintaning User Fees for Municipatities; The Local Goverment ProgramDepartemen of Political Science". Paper MPA Research, University of Western Otario..

Mardiasmo. 2002. Otonomi \& Manajeman Keuangan Daerah. BPFE. Yogyakarta.

Republik Indonesia. 1999. Undang-Undang Otonomi Daerah 1999. Sinar Grafika. Jakarta. 